\title{
NEGATIVE PRESSURE WOUND THERAPY (NPWT) FOR THE MANAGEMENT OF DIABETIC FOOT WOUND
}

\author{
Wesiana Heris Santy \\ (UNUSA ,FIK. prodi S1 Keperawatan, Jln SMEA 57 Surabaya) \\ wesiana@unusa.ac.id/wesiana@yahoo.co.id
}

Abstract : Complications often experienced by people with diabetes are complications in the feet $(15 \%$ ) called diabetic foot (Akhtyo , 2009). Where the injury to the leg if not treated properly will lead to infections and ultimately need to be amputated .The purpose of writing articles is to review and discuss the evidence-based literature bersadarkanpraktice of Negative Pressure Wound Therapy Effectiveness ( NPWT ) ) on the healing of diabetic foot ulcers.One technology that is used to prevent and avoid lower limb amputation is the technique of negative pressure or Negative Pressure Wound Therapy ( NPWT ) ). This negative pressure technique has grown rapidly and now has been widely used in many countries, especially in Western European countries ( Germany) and the United States . Negative pressure technique has the advantage that it is relatively cheaper cost than the use of hyperbaric oxygen . Results obtained by several studies that the use of NPWT may improve wound healing process through efforts to create a moist wound environment and decrease edema that becomes optimal wound healing, throw that out of the wound exudate so that the protease enzyme in the exudate also go wasted, this enzyme is known to interfere wound healing process . The other benefit is that it can stimulate cell growth by increasing angiogenesis physically, so that the growth of new cells will be maximal

Abstrak : Komplikasi sering dialami pengidap diabetes adalah komplikasi pada kaki (15\%) disebut kaki diabetes (Akhtyo, 2009).Dimana luka pada kaki jika tidak ditangani dengan baik akan menyebabkan terjadinya infeksi dan akhirnya perlu di amputasi. Tujuan penulisan artikel adalah mengkaji dan membahas literature bersadarkan evidence based praktice tentang Efektifitas Negative Pressure Wound Therapy (NPWT)) pada penyembuhan ulkus kaki Diabetik. Salah satu teknologi yang digunakan untuk mencegah dan menghindari amputasi ekstremitas bawah adalah teknik tekanan negatif atau Negative Pressure Wound Therapy $(N P W T)$ ). Teknik tekanan negatif ini telah berkembang dengan pesat dan sekarang ini telah banyak digunakan di berbagai negara, terutama di negara Eropa Barat (Jerman) dan Amerika Serikat. Teknik tekanan negatif mempunyai keuntungan yaitu biaya relatif lebih murah dibandingkan penggunaan hiperbarik oksigen. Hasil yang diperoleh berdasarkan beberapa penelitian yaitu penggunaan NPWT dapat meningkatkan proses penyembuhan luka melalui upaya penciptaan lingkungan luka yang lembabdanmenurunkan edema sehingga penyembuhan luka menjadi optimal, membuang eksudat yang keluar dari luka sehingga enzim protease di dalam eksudat juga ikut terbuang, enzim ini diketahui mengganggu proses penyembuhan luka. Manfaat lainnya yaitu dapat menstimulasi pertumbuhan sel secara fisik dengan meningkatkan angiogenesis, sehingga pertumbuhan sel baru akan maksimal.

Kata Kunci : Diabetes Mellitus, ulkus kaki, tekanan negatif 


\section{PENDAHULUAN}

Diabetes Melitus merupakan sekelompok kelainan heterogen yang ditandai oleh kenaikan kadar glukosa darah atau hiperglikemia (Brunner \& Sudarth, 2001). Komplikasi yang sering dialami pengidap diabetes yaitu komplikasi pada kaki (15\%) disebut kaki diabetes (Akhtyo, 2009)Diabetes mellitus dapat mengakibatkan kerusakan pada beberapa organ tubuh, seperti mata, saraf dan ginjal serta berpotensi berkembangnya proses penyakit aterosklerosis yang akan berefek pada gangguan jantung, otak dan organ lain dalam tubuh (Indofamilyhealth, 2008).Organisasi kesehatan dunia atau World Health Organization (WHO) (2007) memprediksi penderita diabetes akan menjadi sekitar 366 juta orang pada tahun 2030. Penyumbang terbesar peningkatan angka tersebut adalah negara-negara berkembang, diantaranya India (35,5 juta orang), Cina (23,8 juta orang), Amerika Serikat (16 juta orang), Rusia (9,7 juta orang), dan Jepang (6,7 juta orang) (Arief, 2007).Sedangkan lima negara dengan prevalensi diabetes tertinggi penduduk dewasanya adalah Nauru (30,2\%), Uni Emirat Arab (20,1\%), Qatar (16\%), Bahrain (14,9\%), dan Kuwait (12,8\%). Yang lebih buruk, setidaknya 50\% penderita diabetes tidak menyadari kondisi mereka, dan di beberapa negara jumlahnya mencapai 80\% (Arief, 2007).

Menurut survei yang dilakukan oleh WHO (2005), Indonesia menempati urutan ke-4 terbesar dalam jumlah penderita diabetes mellitus dengan prevalensi 8,6\% dari total penduduk dengan urutan teratas India, Cina dan Amerika Serikat. Temuan tersebut semakin membuktikan bahwa penyakit diabetes mellitus merupakan masalah kesehatan masyarakat yang sangat serius (Depkes RI, 2005).

Peter Cavanagh pakar kaki diabetik dari Claveland US, menyoroti problem kaki di masa yang akan datang, dimana pada tahun 2032 seiring dengan peningkatan jumlah penyandang diabetes melitus di dunia akan terjadi pula lonjakan masalah kaki diabetik. Di negara China, dengan jumlah penduduk yang lebih dari 1 milyar, saat ini diperkirakan terdapat 40 juta penyandang diabetes, jika diperkirakan $10 \%$ diantaranya mengalami problem kaki diabetik maka akan terdapat 4 juta penyandang diabetes yang mengalami problem kaki dibetik. Publikasi mengenai kaki diabetikpun mulai meningkat dari 6 buah pada tahun 1996 menjadi 306 pada tahun 2005. Data WHO, saat ini Indonesia menempati urutan ke-4 terbesar dalam jumlah penderita diabetes Melitus di dunia. Pada tahun 2006 jumlah Diabetasi di Indonesia diperkirakan mencapai 14 juta orang, dimana baru $50 \%$ yang sadar mengidapnya dan diantara mereka baru sekitar $30 \%$ yang datang berobat teratur (WHO 2008 dalam Candra, 2008).

Gangguan kesehatan komplikasi Diabetes Melitus antara lain gangguan mata retinopati, gangguan ginjal nefropati, gangguan pembuluh darah vaskulopati, dan kelainan pada kaki. Komplikasi yang paling sering adalah terjadinya perubahan patologis pada anggota gerak bawah yang disebut kaki diabetik diabetic foot. Dalam kondisi keadaan kaki diabetik, yang terjadi adalah kelainan persarafan neuropati, perubahan struktural, tonjolan kulit kalus, perubahan kulit dan kuku, luka pada kaki, infeksi dan kelainan pembuluh darah. Neuropati perifer (kerusakan saraf) merupakan komplikasi serius dari diabetes. Data terbaru menunjukkan bahwa satu dari 5 orang dengan diabetes $(20 \%)$ memiliki neuropati perifer. Risiko neuropati perifer adalah sekitar 2 kali lipat lebih tinggi dibandingkan orang tanpa diabetes. Kombinasi neuropati perifer dengan masalah yang terkait dengan suplai darah ke kaki dapat menyebabkan ulkus kaki dan penyembuhan luka lambat. Infeksi ini dapat mengakibatkan luka amputasi, 40$70 \%$ dari seluruh amputasi ekstremitas bawah disebabkan oleh Diabetes Melitus. Keadaan kaki diabetik lanjut yang tidak ditangani secara tepat dapat berkembang menjadi suatu tindakan pemotongan amputasi kaki. Adanya luka dan masalah 
lain pada kaki merupakan penyebab utama kesakitan morbiditas, ketidakmampuan disabilitas, dan kematian mortalitas pada seseorang yang menderita diabetes melitus (Prabowo, 2007). Komplikasi yang paling sering dialami pengidap diabetes adalah komplikasi pada kaki (15 persen) yang kini disebut kaki diabetes(Akhtyo, 2009). Diabetes Melitus adalah sebagai penyebab utama amputasi ekstremitas bawah non traumatic di Amerika Serikat.Amputasi kaki karena diabetes merupakan 50\% total amputasi di Amerika Serikat. Data dari RSUPN Cipto Mangunkusumo Jakarta menunjukkan bahwa angka amputasi juga masih sangat tinggi, yaitu sebesar $23 \%$. Didapatkan pula bahwa $30-50 \%$ pasien yang telah diamputasi akan memerlukan tindakan amputasi kaki sebelahnya dalam jangka 1 - 3 tahun. Dalam 1 tahun pasca amputasi $14,8 \%$ meninggal dan meningkat $37 \%$ pada pengamatan 3 tahun.

Penatalaksanaan ulkus kaki diabetik terutama difokuskan untuk mencegah dan menghindari amputasi ekstremitas bawah. Sehingga penting bagi seorang perawat untuk melakukan penilaian ulkus kaki diabetik secara menyeluruh dan melakukan perawatan dengan baik. Lebih dari 90\% ulkus akan sembuh apabila diterapi secara komprehensif multidisipliner. Misalnya melalui upaya mengatasi penyakit komorbid, menghilangkan/ mengurangi tekanan beban (offloading), menjaga luka agar selalu lembab, penanganan infeksi, debridemen, revaskularisasi dan tindakan bedah elektif, profilaktik, kuratif atau emergensi sesuai dengan indikasi. Penatalaksanaan penyakit DM melibatkan sistem multi organ yang akan mempengaruhi penyembuhan luka. Hipertensi, hiperglikemia, hiperkolesterolemia, gangguan kardiovaskular (stroke, penyakit jantung koroner), gangguan fungsi ginjal dan sebagainya harus dikendalikan. Penatalaksanaan keperawatan yang dilakukan meliputi debridemen, mengurangi beban tekanan (off loading), dressing, dan pengendalian.
Masalah pengelolaan ulkus kaki diabetik merupakan masalah yang rumit dan sampai saat ini pengelolaannya tidak maksimal. Selain penerapan IPTEKS yang masih sangat minim, yaitu hanya dengan kompres basah dengan kassa (moist gauze) hal ini juga diperparah oleh ketidaktahuan masyarakat mengenai ulkus kaki diabetes dan perawatannya ketika berada di rumah. Penatalaksanaan mutakhir terkait dengan ulkus kaki diabetik diantaranya adalah penggunaan hiperbarik oksigen dan teknik tekanan negatif (Negative Pressure Wound Therapy/Vacuum Assisted Closure (VAC)). Teknik tekanan negatif ini telah berkembang dengan pesat dan sekarang ini telah banyak digunakan di berbagai negara, terutama di negara Eropa Barat (Jerman) dan Amerika Serikat. Teknik tekanan negatif mempunyai keuntungan yaitu biaya relatif lebih murah dibandingkan penggunaan hiperbarik oksigen.

\section{TUJUAN}

Tujuan penulisan artikel adalah mengkaji dan membahas literature bersadarkan evidence based praktice tentang Efektifitas Negative Pressure Wound Therapy $(N P W T)$ ) pada penyembuhan ulkus kaki Diabetik

\section{KAJIAN LITERATURE \\ Sirkulasi darah pada kaki pasien Diabetes Melitus}

Sirkulasi darah adalah aliran darah yang dipompakan jantung ke pembuluh darah dan dialirkan oleh arteri ke seluruh organorgan tubuh (Hayens, 2003) salah satunya pada organ kaki. Normal sirkulasi darah pada kaki menurut (Vowden, 2001) adalah 1,0 yang diperoleh dari rumus ABPI(An ankle Brachial Pressure Index). Sedangkan keadaan yang tidak normal dapat diperoleh bila nilai ABPI $<0,9$ diindikasikan ada resiko tinggi luka di kaki, $\mathrm{ABPI}>0,5$ dan $<0,9$ pasien perlu perawatan tindak lanjut, dan ABPI < 0,5 diindikasikan kaki sudah mengalami kaki nekrotik, gangren, ulkus, borok yang perlu penanganan dokter ahli bedah Vaskular. 
Dasar terjadinya luka atau kelainan pada kaki pasien penderita diabetes adalah adanya suatu kelainan pada saraf, kelainan pembuluh darah dan kemudian adanya infeksi. Dari ketiga hal tersebut, yang paling berperan adalah kelainan pada saraf, sedangkan kelainan pembuluh darah lebih berperan nyata pada penyembuhan luka sehingga menentukan nasib kaki. Keadaan kelainan saraf dapat mengenai saraf sensorik, saraf motorik, dan saraf otonom (Prabowo, 2007).

Bila mengenai saraf sensoris akan terjadi hilang rasa yang menyebabkan penderita tidak dapat merasakan rangsang nyeri sehingga kehilangan daya kewaspadaan proteksi kaki terhadap rangsang dari luar. Akibatnya, kaki lebih rentan terhadap luka meskipun terhadap benturan kecil. Bila sudah terjadi luka, akan memudahkan kuman masuk yang menyebabkan infeksi. Bila infeksi ini tidak diatasi dengan baik, hal itu akan berlanjut menjadi pembusukan (gangren) bahkan dapat diamputasi (Prabowo, 2007).

Gangguan pada serabut saraf motorik (serabut saraf yang menuju otot) dapat mengakibatkan pengecilan atrofi otot interosseus pada kaki. Akibat lanjut dari keadaan ini terjadi ketidakseimbangan otot kaki, terjadi perubahan bentuk deformitas pada kaki seperti jari menekuk cock up toes, bergesernya sendi luksasi pada sendi kaki depan metatarsofalangeal dan terjadi penipisan bantalan lemak di bawah daerah pangkal jari kaki kaput metatarsal. Hal ini menyebabkan adanya perluasan daerah yang mengalami penekanan, terutama di bawah kaput metatarsal (Prabowo,2007).

Selain itu, terjadi perubahan daya membesar-mengecil pembuluh darah vasodilatasi-vasokonstriksi di daerah tungkai bawah, akibatnya sendi menjadi kaku. Keadaan lebih lanjut terjadi perubahan bentuk kaki, yang menyebabkan perubahan daerah tekanan kaki yang baru dan berisiko terjadinya luka (Prabowo, 2007).

Kelainan pembuluh darah berakibat tersumbatnya pembuluh darah sehingga menghambat aliran darah, mengganggu suplai oksigen, bahan makanan atau obat antibiotika yang dapat menggagu proses penyembuhan luka. Bila pengobatan infeksi ini tidak sempurna dapat menyebabkan pembusukan gangren. Gangren yang luas dapat pula terjadi akibat sumbatan pembuluh darah yang luas sehingga kemungkinannya dilakukan amputasi kaki di atas lutut (Igra, 2009).

\section{KONSEP NEGATIVE PRESSURE WOUND THERAPY (NPWT)}

Negative Pressure Wound Therapy (NPWT) atau biasa disebut dengan TNP (Topical Negative Pressure) merupakan terapi non farmakologis yang digunakan dalam penatalaksanaan luka akut maupun kronik, meliputi pressure ulcer (dekubitus), luka diabetik, maupun luka karena trauma. Menurut Fleischmann cit Vikatmaa (2008) konsep penggunaan tekanan negatif ini sebenarnya sudah dikenal sejak tahun 1940an. Namun mulai dikembangkan secara intensif pada tahun 1990 di Jerman dan Amerika Serikat. Perusahaan yang pertama kali mempatenkankan hasil penelitian ini adalah KCI (Kinetic Cncept Inc.) dengan nama Vacuum Asissted Closure (V.A.C).

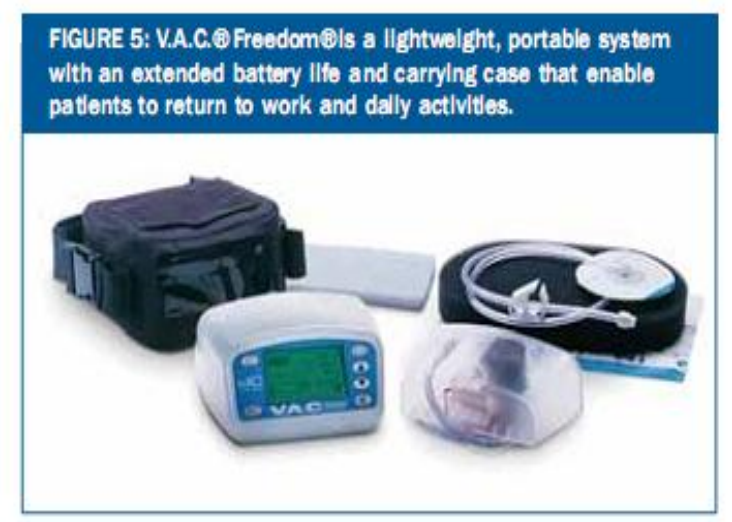

\section{Mekanisme Kerja NPWT/ VAC}

Penggunaan NPWT dilakukan dengan cara memberikan tekanan negatif lokal di permukaan luka. Permukaan luka akan tertutup oleh air tight film yang terhubung dengan suction tube (terhubung dengan control unit) yang mempunyai tekanan negatif terhadap permukaan luka dengan 
tekanan 50-175 mmHg. Biasanya yang sering digunakan adalah $125 \mathrm{mmHg}$. Cairan yang disuction akan dikumpulkan dalam sebuah container pada control unit (Kirby, 2007)

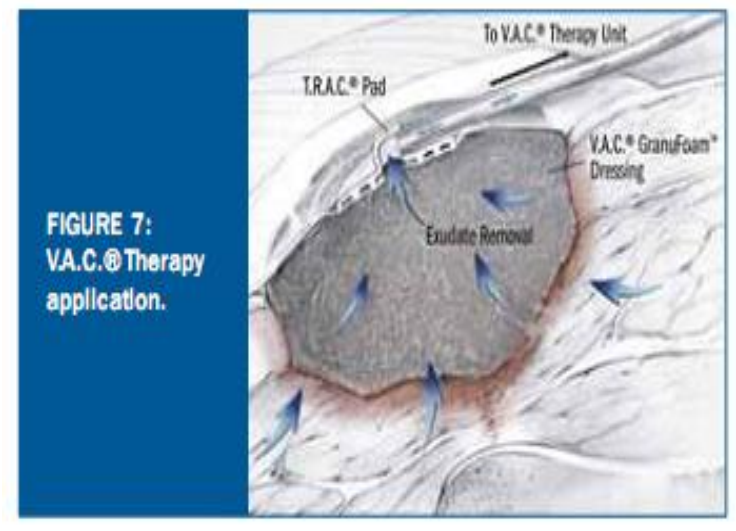

Mekanisme NPWT dalam proses penyembuhan ulkus kaki diabetik adalah mempertahankan lingkungan luka tetap lembab (moist), membuang cairan dan material infeksi, menurunkan kolonisasi bakteri, meningkatkan formasi granulasi jaringan, pertumbuhan sel yang lebih cepat, meningkatkan aliran darah lokal, menurunkan jumlah bakteri, dan membuang protease yang membahayakan proses penyembuhan luka (MendezEastman S. cit Kirby 2007).

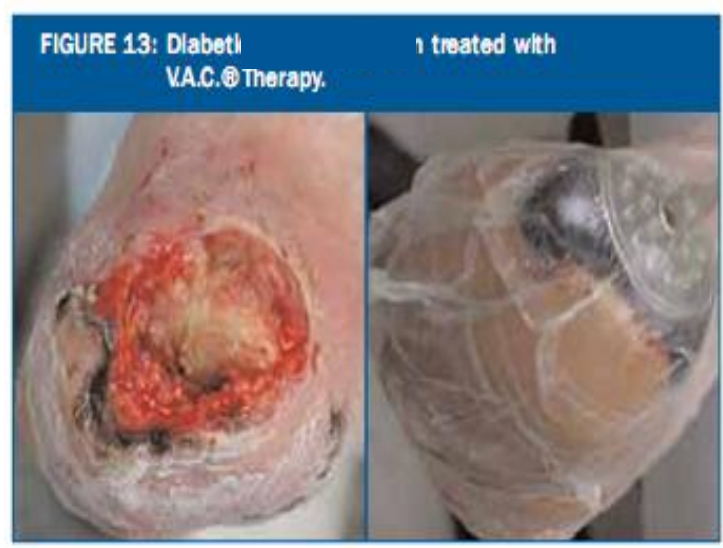

Penelitian yang dilakukan oleh Blume et al(2008) mengatakan bahwa penggunaan NPWT (V.A.C) dapat meningkatkan proses penyembuhan luka melalui upaya penciptaan lingkungan luka yang lembabdanmenurunkan edema.

Secara umum Andros et al (2005) menyatakan kelebihan metode NPWT dibanding dengan metode yang lain adalah metode ini dapat menyediakan lingkungan yang lembab, sehingga penyembuhan luka menjadi optimal, membuang eksudat yang keluar dari luka sehingga enzim protease di dalam eksudat juga ikut terbuat, enzim ini diketahui mengganggu proses

penyembuhan luka. Selain itu kelebihan yang lainnya adalah kontrol infeksi, dimana pada hari ke-4 dan ke-5 luka yang tidak menggunakan NPWT jumlah bakteri dan kolonisasi bakteri meningkat. Sedangkan pada penggunaan NPWT hal ini tidak nampak. Kelebihan yang lainnya adalah NPWT dapat menstimulasi pertumbuhan sel secara fisik dengan meningkatkan angiogenesis, sehingga pertumbuhan sel baru akan maksimal. Hasilpenelitianinitidakdidukungsepenuhny aolehMouësaet al (2006) yang menyatakanpadapasien yang mendapatterapi NPWT, lukamemangmenjadilebih cepat sembuh danluaspermukaanlukajugamengalamipenu runandengancepatdibandingkan pada terapi konventional.Namun demikian jumlah kolonisasi bakteri tidak menunjukkan perbedaan yang signifikandiantaraduakelompok.

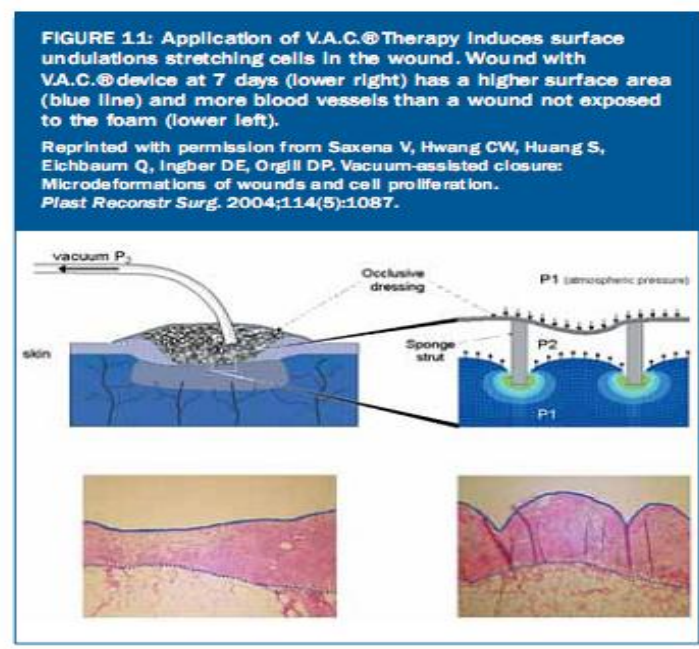

\section{Indikasi dan Kontraindikasi}

Menurut Fleck dan Frizzell cit Kirby (2007) indikasi penggunaan terapi ini adalah terutama paling cocok digunakan untuk luka stage III dan stage IV dengan granulasi yang jelek atau tidak mencukupi dan eksudate yang berlebihan. Secara umum, penggunaan NPWT dapat dipertimbangkan untuk luka kronik, jika 
ukuran luka hanya berkurang sedikit ( $<30$ $\%)$ setelah 4 minggu perawatan dengan debridement atau jika eksudat tidak dapat dikontrol secara efektif dengan dressing harian. Indikasi penggunaan NPWT berdasarkan Konsensus yang disetujui oleh US Food and Drug Administration (FDA) selain untuk ulkus kaki diabetic adalah untuk pressure ulcer, luka kronik, luka akut dan traumatik, luka dehisiensi, luka bakar parsial, dan luka pada flaps dan graft (Andros, 2005).

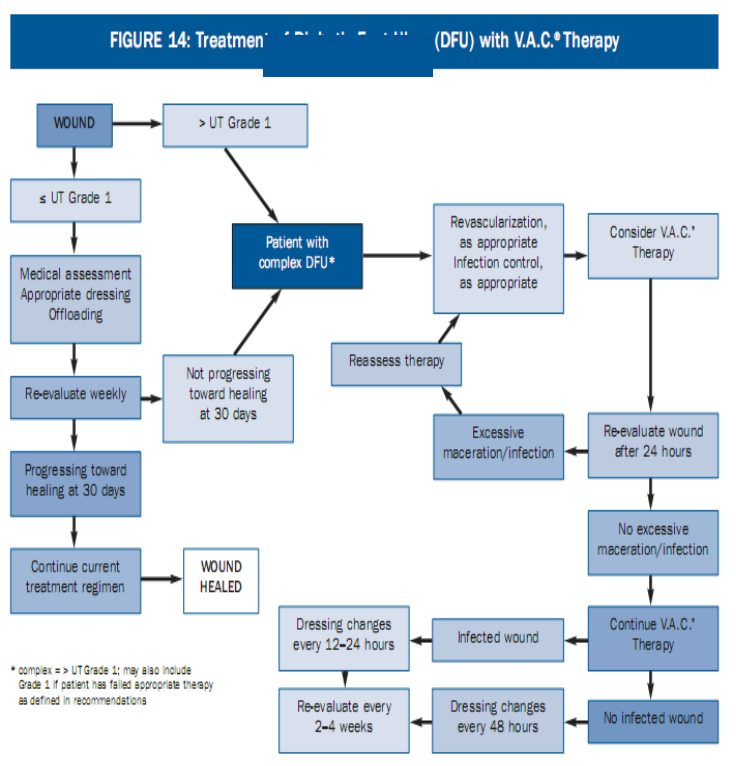

\section{Efek Samping}

Penerapan NPWT pada pasien harus dilakukan pada saat yang tepat. Kelemahan-kelemahan dari terapi harus dipertimbangkan. Kebutuhan akan tenaga kesehatan yang professional (perawat) harus menjadi pertimbangan utama. Sehingga perawat harus mempunyai ketrampilan dan pengetahuan yang baik terhadap terapi ini dan kapan keputusan penggunaan terapi ini digunakan. Menurut Fleck dan Frizzell cit Kirby (2007) efek samping yang dialami oleh pasien mungkin adalah mengalami ketidaknyamanan atau nyeri ketika cairan dressing diganti. Tekanan yang digunakan harus ditentukan berdasarkan derajat nyeri yang dirasakan pasien. Jika nyeri menetap setelah penggurangan tekanan maka terapi NPWT seyogyanya dihentikan. Nyeri yang dirasakan akan sedikit dikacaukan karena nyeri mungkin berhubungan dengan tekanan negative ini atau dari luka itu sendiri. Masalah pada kulit secara topikal mungkin muncul selama penggunaan NPWT, yaitu munculnya infeksi jamur, candida, dan subepidermal granulasi. Namun hal ini jarang terjadi. Jika selama 7 atau 8 hari penggunaan NPWT tidak menunjukkan hasil yang positif, indikasi penggunaan terapi ini dapat dievaluasi lagi dan Terapi seharusnya dihentikan jika muncul pus terus menerus dari dressing atau terjadi perdarahan yang berlebihan.

\section{REVIEW BEBERAPA HASIL PENELITIAN}

Penggunaan metode NPWT dapat diaplikasikan dalam perawatan luka kaki diabetik. Hal ini diperkuat dengan beberapa penelitian terkait yang menunjukkan efektivitas dan keamanan penggunaan metode ini. Menurut Kirby (2007) publikasi penelitian tentang efektivitas terapi NPWT lebih dari 325 publikasi, dimana 15 diantaranya adalah penelitian dengan menggunakan metode RCT menunjukkan hasil yang positif terhadap penggunaan metode ini. Hasil penelitian ini juga didukung oleh Deva et al (2000) dengan design penelitian prospective concecutive patient series yang menunjukkan hasil bahwa dengan penggunaan Topical Negative Pressure (TNP) mempercepat penyembuhan luka kurang dari 6 minggu, dan menurunkan jumlah bakteri dan kolonisasi bakteri. Memang ada beberapa penelitian yang menghendaki dilakukan penelitian yang lebih besar dan dengan kualitas yang baik, diantaranya adalah Vikatmaa (2008).

Namun Vikatama juga tidak menolak bahwa ada bukti tentatif terhadap penggunaan metode ini. Dari segi pembiayaan, penggunaan NPWT juga tidak menimbulkan ekstra cost bagi pasien. Hasil peneilitian Mause cit Kirby (2007) menunjukkan bahwa penggunaan NPWT dan terapi standar mengugunakan kassa lembab (moist gauze) juga tidak 
menunjukkan perbedaan yang signifikan.Oleh karena itu sampai saat ini kita mempunyai bukti-bukti yang mendasar dan berdasarkan hasil pengalaman klinis bahwa penggunaan NPWT dapat diterapkan dengan biaya yang juga relatif sama dengan terapi standar. Lavery (2007) denganpenelitiannnyatentangpemakaian NPWT di rumahjugamenyatakanbahwaselain proses penyembuhanmenjadilebihcepatdarisegibia yasebenarnyatidakjauhberbedaantarapengg unaan NPWT denganterapikonvensionalkassa.

Bukti klinis dari hasil penelitian studi kasus dan study cohort, mayoritas hasil penelitian menunjukkan bahwa efek penggunaan NPWT dapat menurunkan ukuran luka dan membantu proses penyembuhan luka. Hasil penelitian prospective randomized trial terhadap 24 pasien dengan luka kronik, non healing yang dilakukan oleh Joseph et al (2000) cit Kirby (2007) dengan membandingkan penggunaan NPWT dengan dressing normal saline menunjukkan bahwa luka yang diterapi dengan NPWT (VAC system) $64 \%$ pasien menunjukkan granulasi jaringan yang baik sedangkan $81 \%$ pasien yang diterapi dengan normal saline menunjukkan adaya inflmasi dan fibrosis pada jaringan luka.

Dalam beberapa penelitian yang dilakukan terhadap keamanan dan efikasi dari NPWT dalam penatalaksanaan diabetic foot ulcer disebutkan bahwa NPWT (Negative Pressure Wound Therapy) lebih aman dan efektif dari pada penggunaan AMWT (Advanced Moist Wound Therapy) dengan prodominan hydrogels and alginates. Blume, et.al (2008) melalui penelitian multicenter randomized control trial menyebutkan bahwa dalam 112 hari, penutupan secara komplet terhadap luka kaki diabetik dengan NPWT adalah 43,2 \% (73 dari 169 orang) sedangkan dengan AMWT hanya 28,9 \% (48 dari 166 orang) dengan p 0,007.
Perkiraan median dengan Kaplan-Meier menunjukkan $100 \%$ luka akan menutup dalam 96 hari sedangkan dengan AMWT tidak dapat ditentukan. Pasien yang menggunakan NPWT juga menunjukkan bahwa kejadian amputasi kedua (secondary amputation) akan berkurang dengan signifikan ( $\mathrm{p} ; 0.035)$.

penilaian terhadap keamanan penggunaan NPWT dan AMWT dalam 6 bulan penelitian tidak menunjukkan perbedaan signifikan. Dalam suatu study retrospektif yang dilakukan oleh Claire et al (2002) mengenai penggunaan NPWT (V.A.C) pada pasien non-healing wound di ekstrimitas bawah pada 17 orang pasien (14 orang diantaranya pasien diabetes) yang mengalami kegagalan dengan penggunaan debridement dan dressing standart selama rata-rata 8,2 minggu disebutkan bahwa dari 17 pasien 14 pasien mencapai penyembuhan luka yang baik.

Dari segi pembiayaan, penggunaan NPWT dan Conventional Therapy (moist gauze) juga tidak menunjukkan perbedaan yang signifikan. Hasil penelitian di Belanda yang dilakukan oleh Mause cit Kirby (2007) menunjukkan bahwa tidak ada perbedaan yang signifikan antara NPWT dan Conventional Therapy, yaitu untuk NPWT biaya yang diperlukan adalah euro 2,204 $\pm 1,282$ Euro dan untuk Conventional Therapy adalah 2,529 $\pm 1,365$.

Namun demikian yang menjadi pertimbangan dalam penerapan metode ini adalah hasil penelitian systematic review terhadap 14 penelitian Randomized Controled Trial (RCT) mengenai keamanan dan efekasi NPWT pada luka pressure ulcer, ulkus kaki diabetic, luka kronis miscellaneous yang dilakukan oleh Vikatmaa et al (2008) menunjukkan bahwa dari sekian banyak penelitian memang menyatakan bahwa NPWT aman dan efek samping serius jarang dilaporkan dan juga lebih efektif daripada terapi standar yang biasa dilakukan.

Andros et al (2005) menyatakan bahwa indikasi dan kontraindikasi penerapan terapi ini harus dipahami dengan baik oleh 
perawat. Indikasi terapi ini adalah untuk penyembuhan luka kaki diabetik, pressure ulcer, luka kronis, luka akut dan traumatic, luka defisiensi bedah, luka bakar parsial, dan luka flaps atau graft. Sedangkan kontraindikasinya adalah luka dengan malignasi, osteomyelitis yang tidak terobati, fistula yang tidak terekspose, jaringan nekrotik dengan timbulnya eschar, dan luka pada organ dan pembuluh darah yang terbuka. Untuk luka osteomyelitis terapi ini dapat digunakan dengan mengkombinasikannya dengan debridement dan pemberian antibiotic topical.

Selain itu perawat juga harus memperhatikan hal-hal berikut diantaranya adalah infeksi, potensial perdarahan, penggunaan terapi antikoagulan, keganasan, kepatuhan pasien, pengurangan beban (offloading) dan ambulasi di rumah. Jika di daerah luka diperkirakan terdapat infeksi, maka terapi debridement dan pemberian antibiotik merupakan terapi utama. NPWT hanya bersifat sebagai terapi adjuvant saja. Potensial perdarahan bisa terjadi, sehingga perlu dilakukan monitoring yang ketat terhadap drainase cairan yang keluar pada container. Jika perdarahan yang excessive terjadi, sebaiknya penggunaan metode ini dihentikan. Penggunaan NPWT pada pasien yang mendapatkan terapi antikoagulan harus menjadi perhatian dokter dan perawat yang merawatnya. Jika muncul perdarahan, hendaknya tekanan negatif diturunkan dan jika perdarahan terus berlanjut setelah penurunan tekanan, maka hendaknya terapi dihentikan. Pada kasus keganasan, terapi ini tidak diindikasikan karena dapat meningkatkan pertumbuhan sel kanker. Selain itu kepatuhan pasien selama penggunaan alat dalam terapi ini sangatlah penting, kerena pasien harus tetap melakukan ambulasi dengan baik, dan banyak istirahat. Pada pasien ulkus diabetic yang mengalami dementia terapi ini juga sangat efektif namun harus dengan pengawasan.

\section{SIMPULAN}

1. Penerapan NPWT dapatmeningkatkan proses

penyembuhanlukamelaluiupayapencipta anlingkunganluka yang lembab,menurunkan, udema, membuangeksudat yang keluardarilukasehinggaenzim protease di dalameksudatjugaikutterbuang, menstimulasipertumbuhanselsecarafisik denganmeningkatkan angiogenesis, sehinggapertumbuhanselbaruakanmaksi mal.

2. Penerapanprosedur NPWT efektif dilakukan pada luka uka stage III dan stage IV dengangranulasi yang jelekdaneksudate yang berlebihan,lukakronik, jikaukuranlukahanyaberkurangsedikit $\left(\begin{array}{llll}(<30 & \%\end{array}\right) \quad$ setelah 4 mingguperawatandengan debridement ataujikaeksudattidakdapatdikontrolsecar aefektifdengan dressing harian.

3. Diperlukan pemahaman dan ketrampilan perawat yang baik dalam penggunaan NPWT baik tentang cara penggunaan, indikasi dan kontrainsikasi serta observasi yang ketat agar proses penyembuhan bisa optimal.

\section{DAFTAR PUSTAKA}

Andros, George et.al, (2005). Consensus Statement on Negative Pressure Wound Therapy (V.A.C.® Therapy) for the Management of Diabetic Foot Wounds. OWM Jounal. June 2005.http://www.owm.com/files/docs/071406_kci.pdf. didownload pada tanggal 3 Juni 2013.

Blume, Peter A. et.al (2008). Comparison of Negative Pressure Wound Therapy Using Vacuum-Assisted Closure With Advanced Moist Wound 
Therapy in the Treatment of Diabetic Foot Ulcers. Diabetes Care Journal. April 2008.

http://care.diabetesjournals.org/conte nt/31/4/631.full.pdf+html.

Didownload pada tanggal 12 Juni 2010

C. Smeltzer, Susan. (2002). Buku Ajar Keperawatan Medikal-Bedah Brunner \& Suddarth Ed. 8.Jakarta: EGC.

Claire, Michael P. et al (2002). Experience with Vacuum Assited Closure Negative Pressure Technique in the Treatment of Non-healing Diabetic and Disvasular Wound. American Orthopaedic and Ankle Society. Ink. http://www.efe.com.br/arquivos/Exp eriência com a Técnica de Pressão Negativa do V.A.C. .pdf. didownload pada tanggal 12 Juni 20103

Deva, AK., et al (2000). Topical Negative Pressure in Wound Management. Med J Aust. 2000 Aug 7;173(3):12831. http://www.ncbi.nlm.nih.gov/ pubmed/10979377. didownload pada tanggal 12 Juni 2013.

Etöz, Abdullah, et al. (2004). The Use of Negative Pressure Wound Therapy on Diabetic Foot Ulcers: A Preliminary Controlled Trial, http://www.woundsresearch.com/arti cle/2941, didownload pada tanggal 17 Juni 2013

Kilpadi, Deepak V. et al (2006). Composition of Wound Fluid From Pressure Ulcers Treated With Negative Pressure Wound Therapy Using V.A.C. Therapy in Home Health or Extended Care Patients: A Pilot

Study,http://www.medscape.com/vie warticle/533859_1, didownload pada tanggal 15 Juni 2013
Kirby, Michael. (2007). Negative Pressure Wound Therapy. The British Journal of Diabetes \& Vascular Disease. http://dvd.sagepub.com/content/7/5/2 30.full.pdf+html, didownload pada tanggal 15 Juni 2013.

Lanywati, Endang (2007). Diabetes Melitus Penyakit Kencing Manis. Yokyakarta: Kanisius.

Lavery, Lawrence A. et al. (2007).A comparison of diabetic foot ulcer outcomes using negative pressure wound therapy versus historical standard of care. http://onlinelibrary.wiley.com/doi/10 $.1111 / \mathrm{j} .1742-$ 481X.2007.00317.x/full, didownloadpadatanggal2 Juni 2013

Mouësa C.M. et al (2006).Comparing conventional gauze therapy to vacuum-assisted closure wound therapy: A prospective randomised trial.http://www.jprasurg.com/article /S1748-6815\%2806\%2900348-

2/abstract, didownload pada tanggal 7Juni 2013

Sudoyo, Aru dkk (2006). Buku Ajar Ilmu Penyakit Dalam. Jilid III Edisi IV. Jakarta : Pusat Penerbitan Departemen Ilmu Penyakit Dalam Fakultas Kedokteran Universitas Indonesia

Sujono \& Sukarmin (2008). Asuhan Keperawatan pada Pasien dengan Gangguan Eksokrin \& Endokrin pada Pankreas. Yogyakarta: Graha Ilmu.

Tjokronegoro, Arjatmo (1996). Buku Ajar Ilmu Penyakit Dalam Jilid I. Jakarta: Balai Penerbit FKUI.

Ubbink DT, et al (2008). Topical negative pressure for treating chronic wounds. 
http://www.journals.elsevierhealth.co $\mathrm{m} /$ periodicals/bjps/article/S0007-

$1226 \% \quad 2801 \% 2993547-7 /$ abstract, didownloadpadatanggal12Juni 2013

Vikatama, P., et.al (2008). Negative Pressure Wound Therapy: a Systematic Review on Effectiveness and Safety. http://www.ejves.com/article/S10785884\%2808\%2900333-X/pdf.

didownload pada tanggal 18 Juni 2013 